\title{
Utilization of E-Learning as Media in Indonesian Language Courses in Higher Education Post COVID-19 Pandemic
}

\author{
Andi Febri Herawati', Alfitriani Siregar², Yusrizal3, Anita Ade Rahma4, Avid \\ Leonardo Sari5, Irwandi6
}

DOI: $10.35445 /$ alishlah.v13i3.1455

\begin{tabular}{l}
\hline Article Info \\
\hline Keywords: \\
E-Learning, Learning \\
Media, Indonesian \\
Language Education, \\
COVID-19.
\end{tabular}

Kata kunci:

E-Learning, Media

Pembelajaran,

Pendidikan Bahasa

Indonesia, COVID-19.

\begin{abstract}
The rapid development of technology has increased the demand for information technology-based learning media, which is becoming increasingly necessary. ELearning, also known as information technology-based learning media, is changing how education is delivered from a traditional to a digital format. At this time, the world is being affected by the COVID-19 pandemic, which is causing restrictions on activities and gatherings and causing difficulties in lectures. Electronic learning, the most widely used learning medium by all groups, is seen as a solution to keep the learning going in higher education, from primary to post-secondary levels of education. The purpose of this study was to investigate the use of E-Learning as a learning medium in the Indonesian language education department of universities following the outbreak of the COVID-19 pandemic. This study uses a qualitative approach with descriptive analysis to implement Indonesian language education learning by taking samples from lecturers who teach Indonesian courses at the Manado State Islamic Institute and Manado State Christian Institute. According to the study's findings, using information technology as a medium of learning in Indonesian language education courses through e-learning is beneficial, particularly in light of the country's ban on face-to-face instruction. Then, the university should continue to develop e-learning to improve the ease and quality of the teaching and learning process, increase student learning effectiveness, and broaden its reach.
\end{abstract}

\begin{abstract}
Abstrak
Pesatnya perkembangan teknologi mengakibatkan kebutuhan akan media pembelajaran berbasis teknologi informasi semakin meningkat. E-Learning, juga dikenal sebagai media pembelajaran berbasis teknologi informasi, mengubah cara penyampaian pendidikan dari format tradisional ke format digital. Saat ini dunia sedang dilanda pandemi COVID-19 yang menyebabkan pembatasan kegiatan dan perkumpulan, serta menyebabkan kesulitan dalam perkuliahan. Media elektronik yang merupakan media pembelajaran yang
\end{abstract}

\footnotetext{
${ }^{1}$ Universitas Tadulako, Palu, Indonesia

Email: herawati.febi18@gmail.com

${ }_{2}^{2}$ Universitas Muhammadiyah Sumatera Utara, Medan, Indonesia

3 Sekolah Tinggi Keguruan Dan Ilmu Pendidikan Amal Bakti, Medan, Indonesia

4 Universitas Putra Indonesia-YPTK, Padang, Indonesia

5 UIN Sunan Gunung Djati, Bandung, Indonesia

${ }^{6}$ UIN Sunan Gunung Djati, Bandung, Indonesia
} 
paling banyak digunakan oleh semua kalangan dipandang sebagai solusi untuk tetap melanjutkan pembelajaran di perguruan tinggi, mulai dari jenjang pendidikan dasar hingga pendidikan menengah. Oleh karena itu, tujuan dari penelitian ini adalah untuk mengetahui pemanfaatan E-Learning sebagai media pembelajaran di jurusan pendidikan bahasa Indonesia perguruan tinggi pasca merebaknya pandemi COVID-19. Penelitian ini menggunakan pendekatan kualitatif dengan analisis deskriptif untuk pelaksanaan pembelajaran pendidikan bahasa Indonesia dengan mengambil sampel dari dosen yang mengajar mata kuliah Bahasa Indonesia di Institut Agama Islam Negeri Manado dan Institut Kristen Negeri Manado. Menggunakan teknologi informasi sebagai media pembelajaran dalam kursus pendidikan bahasa Indonesia melalui e-learning bermanfaat, menurut temuan penelitian, terutama mengingat larangan negara terhadap pengajaran tatap muka. IAIN Manado harus terus mengembangkan e-learning untuk meningkatkan kemudahan dan kualitas proses belajar mengajar, meningkatkan efektivitas belajar mahasiswa, dan memperluas jangkauannya, sesuai dengan temuan penelitian ini.

\section{INTRODUCTION}

The Covid 19 pandemic on education dramatically affects the quantity and quality of human resources. The government issued a regulation to conduct online learning (Bozkurt et al., 2020; Käpplinger \& Lichte, 2020). Formal educational institutions are one of the aspects that are required to be responsive in responding to this epidemic situation. As much as possible, educational institutions must be able to prevent the spread of this virus in their respective educational environments by implementing changes in teaching patterns, from those that usually use face-toface teaching to changing patterns to distance learning with the maximum use of communication technology (Jena, 2020; Osman, 2020). One of the efforts of various formal educational institutions, namely universities, to break the chain of the Covid 19 pandemic until the current New Normal Era, the lecture system is carried out online, namely by using E-learning and Video Conferences, be it zoom cloud meetings, google meet (Iglesias-Pradas. et al., 2021; Sangster et al., 2020).

The traditional face-to-face habituation learning methods are becoming supplanted by faceto-face and online conversations via technology. Distribution and comprehension of educational content, on the other hand, are riddled with challenges. In addition to Neuhauser $(2002,2007)$, Price et al (Bates, 2005; Simonson et al., 2011). Incorporating communication and information technology into the classroom has a number of advantages and problems. El-Hussein \& Cronje's (2010) research indicates that remote learning has a host of additional advantages and downsides. One of the most significant is its great adaptability in resolving the numerous constraints associated with persistent remote learning. Face-to-face education must address this issue in order to ensure that all students, regardless of age, geography, circumstance, or financial situation, have equitable access to a highquality education. Previous researchers that reached nearly the same conclusions concluded that online learning increased self-reliance (Cercone, 2008).

E-learning is a learning model facilitated and supported by information and communication technology (Tam et al., 2018; Kirkwood, 2009). The development of E-Learning provides many benefits like support for increasingly modern learning. The story of Information and Technology (ICT) in education provides convenience for educators, both lecturers and teachers, and students, both students and students (Waycott et al., 2010; Kerimbayev et al., 2017). One of the conveniences in E-Learning learning is more flexibility in delivering material. Both lecturers and students do not have to go to campus and enter class but can be done anywhere, anytime, and under any conditions, if the learning support facilities are optimal (Siritongthaworn et al., 2006; Wu et al., 2010).

The properties of e-learning, among others, include (Clark \& Mayer 2008) Learning can be enhanced by utilizing instructional methods such as providing examples and exercises. Other methods include using has written and visual materials such as words and pictures. Other methods include using media elements such as words and pictures to help students learn. Other methods 
include direct learning centered on teachers or self-directed learning methods. E-learning is a very successful method of learning in the new normal era since students are familiar with the features of the e-learning moodle. According to Seok (2008), "In the 21st century, e-learning is a new type of pedagogy for learning. Instructional designers, facilitators, and subject matter experts who work with e-learning are called teachers "As a matter of fact.

Not only must online learning be communicative and interesting, but it must also be presented in a way that is easy for students to understand (Liaw, 2006; Webb et al., 2004). Learning materials are presented as being taught face-to-face over the internet. Alexander (2001) recommends that e-learning be simple, personal, and rapid to provide interesting and attractive elearning. Students will be able to use available technologies and menus more easily if the e-learning system is straightforward to use. It will allow students to spend more time learning and less time learning how to utilize the system of E-learning. Teachers must be able to engage well with students in front of the class in order to be successful in the classroom (Wahlstedt et al., 2008). This type of personal engagement allows students to receive assistance with all of the issues they confront, both academically and administratively. This will help kids feel cared for even if they aren't fulfilling the teacher's expectations (Loyens et al., 2008). Complaints and other student requirements should be addressed quickly and efficiently. As a result, the instructor or manager is able to implement learning enhancements (Goyal, 2012).

The application of online learning using E-learning for learning during the New Normal period is simple when the learning management system module is used. The learning management system module makes it possible. According to Munir (2009), various concepts of developing learning sites or e-learning websites include 1. They are formulating learning objectives; 2, creating a learning environment; 3, creating a learning environment; 4 and creating a learning environment; 5 , creating a learning environment 6 . Introducing learning materials gives support and convenience for learners studying learning materials; provides service and comfort for learners performing tasks with clear orders and directions; and 7. The learning content adheres to generally acknowledged standards and is appropriate for the learner's current stage of development. 8. Learning resources are supplied systematically and can be used to motivate students to learn; after each learning material, a summary is provided. 9. Learning materials are created according to reality so students can understand, absorb, and practice directly by themselves readily; Using images, examples, and demonstrations to aid learners in understanding, the explanation approach is captivating, straightforward, and simple to comprehend. It can be used to determine learning success by evaluating it and asking students for their feedback on it.

E-Learning is also one of the educational programs to improve teaching ability (Darmayanti et al., 2007). The development of information technology in the current era in education encourages the government to create more quality, effective, efficient, and innovative learning processes (Hadisi \& Muna, 2015). Currently, the world of education is pushing so that the educational curriculum follows digital dynamics, the internet of think, Artificial intelligence, biotechnology (Simarmata et al., 2020). The digital dynamics must be understood and implemented by the community so that education providers, in this case, the government, both the central government under the ministry and local governments under the command of governors and regents, must pay attention to the needs of people with different levels of understanding and knowledge of the use of technology and technology-information in the world of education (Budiman, 2017).

The world of education is never separated from the learning process. This learning process means that lecturers and students carry out two-way activities. The learning process is also the essential indicator compared to the final results that must be achieved (Elyas, 2018). Unfortunately, most students underestimate and take their regular daily activities lightly and place more importance on the Final Semester Examination as the ultimate goal of getting grades even though the normal process has an essential role in learning activities, especially by using E-Learning. 
Indonesian Language Education Course is a field that teaches Indonesian language skills well and effectively, such as listening, speaking, reading, and writing skills. Unlike the Indonesian literature major, Indonesian language education courses are also required to understand the world of education. Being a lecturer is not easy, of course. A lecturer is needed to create an exciting classroom atmosphere, instill character values, and the main task is to convey knowledge. Thus, this course focuses on theories and becoming educators who can understand the Indonesian language. Even this department can create a writer, a transfer language, and even become a journalist. This aspect is the difference between this study and several previous studies.

\section{METHODS}

This research uses the descriptive qualitative method. Qualitative research methods aim to have a significant picture of learning Indonesian in the current New Normal Era (Sugiyono, 2011). Knowing that is being carried out at this time is by using e-learning learning media, which makes it easier for students to access it and learn the material that has been given. The research subjects are lecturers who teach Indonesian Language courses the Manado State Islamic Institute (IAIM Manado) and Manado State Christian Institute (IAKN Manado). The research instruments used to collect data were questionnaires, interviews, and documentation. Dissemination of questionnaires using Google Forms to collect data more effectively during the Covid-19 pandemic.

\section{FINDINGS AND DISCUSSION E-Learning}

E-learning is a type of distant learning notion in and of itself (Mayes \& De Freitas, 2007). The structure of e-learning is rather broad; for example, a portal providing scientific material might be considered an e-learning site. E-learning, also known as internet-enabled learning, is a type of education that blends traditional teaching methods with technological advancements. E-learning is a highly effective learning process that is achieved by integrating the distribution of digital information, which includes assistance and services in learning, with the use of technology (Suharyanto \& Mailangkay, 2008).

It is believed by Hanum (2013) that content plays a vital role in the learning process because it is closely tied to the learning process of participants (students). Content is a learning item that influences the success of e-learning by its kind, content, and weight. Content is classified into three categories: informative, entertaining, and entertaining.

Understanding the three most important aspects of building an effective e-learning program is critical for attracting the attention of teachers and students. It involves making it easy for pupils to use technology and system menus to make it easier. Students will benefit from the ease of use given by the panels, which will shorten the time it takes to get the e-learning system up and running. The teacher must act like a teacher who interacts with students in front of the class to be considered personal. Students' progress can be closely monitored due to more personalized interactions. Additionally, e-learning must include a customer care system and a quick reaction time for students' concerns and requests (Suharyanto \& Mailangkay, 2018).

In e-learning, the traditional learning method is replaced by a more visual and non-verbal approach. Because of this, teachers can supply students (students) with learning materials, control the content being taught, and examine each participant's activities, including online attendance, collecting assignments, and others (Sumiharsono \& Hasanah, 2017). Teachers can also set up online chats with their students, announce certain information, and provide vital feedback for their pupils in these situations. The advantages learning's can be demonstrated in two ways, according to Karwati (2014):

- From the Student's Perspective: e-learning allows for the establishment of a high degree of learning flexibility through technology. This means that students will be able to access 
learning materials at any time and on several occasions. Students can also communicate with their professors at any day or night. Students can better improve their understanding of learning materials if provided with certain circumstances.

- From the perspective of the lecturer, e-learning offers numerous advantages, particularly in the areas of a) making it easier to update learning materials that are their responsibility in response to scientific developments that occur; b) developing yourself or conducting research to increase your knowledge because you have relatively more free time; and c) monitoring and controlling student learning activities. Although this is true, even lecturers can gain insight into when their students are studying, what topics are being explored, how long a case is being investigated, and how many times a particular issue is being revisited; d) determining whether students have completed practice questions after studying specific topics; and e) evaluating student answers and informing students of the results.

\section{Learning Media}

As a teaching and learning aid, learning media is a wide range of media. Anything that piques a learner's interest and stimulates their abilities or skills can help them learn better. This restriction limits the understanding of sources, environment, people, and procedures used for learning/training goals (Tafonao, 2018). In the meantime, learning media, as defined by Briggs (1977), is a tangible medium for disseminating educational information, such as books, films, and videos. According to Clark (1994), learning media is a medium of communication in print and view-hearing and hardware technology, as Clark (1994). Considering that learning takes place in a system, the learning medium has a reasonable position as one of the learning system's components. Communication and, by extension, learning cannot occur at their full potential without the use of media. Because of this, learning material is an essential part of the educational process (Falahudin, 2014). According to this perspective, everything that conveys messages and stimulates students' thoughts, feelings, and eagerness to study is considered teaching media. Arsyad (2016) claims that learning medium has these general properties.

- Educational media is physical in that it can be viewed, heard, and touched with the five senses; this is known as hardware today.

- When it comes to educational media, the term software refers to the message content contained in hardware, which is the content to be conveyed to students by the medium, which is nonphysical.

- Educational media places a heavy emphasis on graphics and sounds.

- Learning aids, both in and out of the classroom, can be defined as educational media.

- Teachers and students communicate and interact with each other via educational media.

- When it comes to educational media, there are a wide range of options available, from mass media (radio and television) to small groups and individuals (e.g., films and slides, videos and OHP).

- Science-related attitudes, activities, organization, strategy, and management.

Learning media has various functions. By definition, these functions are sometimes different; it all depends on the expert who describes them. The following are the functions of learning media:

- Attract students' attention, and sometimes students are less interested or enthusiastic about a lesson because the subject matter is complicated to digest. With learning media, the classroom atmosphere will be fresher, and students can concentrate more, especially when the learning media are unique and exciting.

- Clarify the delivery of messages in lessons, and sometimes there are things with abstract concepts that are difficult to explain orally. For example, the parts of the human body. With 
learning media, such as videos, pictures, or artificial human skeletons. Students will more clearly understand what is explained by the teacher in class.

- Overcome Space, Time, and Cost Limitations When describing, e.g., predatory animals. We can't bring a tiger, lion, or crocodile into the classroom. However, with learning media such as pictures, students understand what the teacher means even though they have not seen the object's shape directly.

- Avoiding Interpretation Errors When the teacher speaks verbally, the student's point of view is sometimes different, and the teacher's intentions are different from the students' understanding. However, with learning media, the interpretation of a theory becomes the same, and there is no misunderstanding of information.

- Accommodating Different Types of Student Learning Styles Humans are equipped with different abilities, including learning styles. In theory, there are at least three learning styles, namely visual, auditory and kinesthetic.

The benefits of learning media mean the results achieved when the functions and goals have been set. Some of the benefits of teaching media, according to Sudjana \& Rivai (2015), are as follows:

- Learning will capture more students' attention, which will result in higher levels of motivation to learn as a result.

- Learning materials will become more obvious in their meaning, allowing students to better comprehend and grasp the learning objectives as a result of the increased clarity.

- Learning methods will be more varied, rather than relying solely on verbal communication through the teacher's words (lectures), in order to prevent pupils from becoming bored and the teacher from being exhausted.

- Because they are paying attention to the teacher's description, students engage in more learning activities; nevertheless, there are also additional activities such as observation, practice, demonstrating, and so on.

Meanwhile, Arsyad (2016) argues that the benefits of learning media are as follows.

- Improve the clarity with which messages and information are presented in order to facilitate and improve learning processes and outcomes.

- Increasing the motivation to learn.

- Overcome the restrictions of one's senses, one's environment, and one's time.

- Share your own personal experiences with pupils about things that are happening in their area.

- There are many different forms of learning media available, including:

- Visual media, such as graphs, diagrams, charts, charts, posters, cartoons, and comic books

- Audial media, which includes radio, tape recorder, language laboratory, and other similar devices

- Projected still media, such as slides, overhead projectors (OHP), in focus, and other similar material

- Projected motion media includes film, television, video (VCD, DVD, VTR), computers, and other similar devices.

In essence, it is not the learning media itself that determines learning outcomes. It turns out that the success of using learning media in the learning process to improve learning outcomes depends on (1) the content of the message, (2) how to explain the message, and (3) the characteristics of the recipient of the message. Thus, it is necessary to pay attention to these three factors in choosing and using media. If these three factors can be conveyed in the learning media, it will undoubtedly give maximum results.

According to Arsyad (2016) in the selection of media should pay attention to the following criteria: 
- Ability to accommodate appropriate stimulus presentation (visual and/or audio).

- Able to accommodate appropriate student responses (written, audio, and/or physical activities).

- Ability to accommodate feedback.

- Selection of primary and secondary media for presenting information or stimuli and for exercises and tests (preferably exercises and tests using the same media).

- Level of enjoyment (preference of institutions, teachers, and students) and cost-effectiveness. Meanwhile, in choosing media, nine factors must be considered, these factors include:

- institutional resource constraints;

- the suitability of the media with the subject being taught;

- characteristics of students or students;

- educator behavior and skill level;

- $\quad$ subject learning objectives;

- learning relationships;

- learning locations;

- $\quad$ timing and degree of media diversity.

\section{Utilization of E-Learning as a Media in Post-Covid-19 Pandemic}

From the results of observations of e-learning used by lecturers of Indonesian language education courses in the IAIN manado and IAKN Manado, it can be explained that at IAIN Manado \& IAKN MAnado, e-learning is used and adapted to the purpose of learning, teaching materials. The materials taught in Indonesian language education courses are speaking skills, listening skills, reading skills, and writing skills. During the COVID-19 pandemic, lecturers were suddenly required to work from home and use e-learning media. The lecturer recognizes that one must be ready and able to effectively carry out the learning process. Therefore, no lecturers teach Indonesian language education courses who do not use e-learning media. At the beginning of the distance learning process, the lecturer in charge of the course used the WhatsApp application as a learning medium for distance learning. On average, after the fourth meeting, all lecturers used various e-learning media during the Mid-Semester Assessment and the Final Semester Assessment.

Lecturers who teach Indonesian language education courses teach all the material well and thoroughly. However, the material is not yet fully understood, and the results are above 75, namely speaking skills and writing skills. Moreover, students sometimes do not attend online lectures due to inadequate internet networks and data. The E-learning media used by lecturers are Zoom, Google Classroom, Zoom, WhatsApp, and email. Lecturers who initially used Google Classroom then switched to using Zoom because they felt it was more effective and efficient as a teacher. After all, it was automatically recorded when class time. The use of zoom is carried out three times in one semester, email for sending assignments from students, and WhatsApp during emergencies, namely, students do not have a strong internet network to use other applications for learning media. The lecturer stated that all these e-learning media could be used effectively for distance learning while adjusting to the teaching materials and task instructions.

Indonesian Language Course taught by one lecturer uses Google Classroom more. This is done because many students majoring in Indonesian in areas far from the city through google classroom lecturers feel it is easier to control students attending lectures. After all, everyone who has downloaded the material is asked to leave comments regarding the material that the lecturer has delivered. For lecturers, this is a practical thing because, besides discussing openly when giving assignments, a deadline for collection can be given. If students do not submit within the specified time limit, they will no longer submit assignments. It trains the discipline and commitment of Islamic Education Management students consisting of two classes and each class. In class A, 
lecturers often use Zoom because it is considered an effective and easy distance learning medium. Zoom made by UBT is very helpful for lecturers used for online learning. Lecturers at the beginning of the meeting until the third meeting used WhatsApp groups to share material, give assignments and discuss. However, after the third meeting, the Indonesian language lecturer in class A1 used Zoom. This zoom provides material, open discussions, collecting assignments, and attendance for both lecturers and students when carrying out learning. There are Indonesian language learning materials that students' scores are still low, namely learning reading skills. The lecturers acknowledge this because students lack printed reference books, lack time to work on many assignments given by other lecturers, and often do not have gadget data pulses. Understanding reading for students is not easy, namely seriousness in reading comprehension, organizing, and processing the information.

The discussion of this research includes an overview of the use of e-learning media in learning Indonesian in the IAIN Manado \& IAKN Manado Program during the COVID-19 pandemic. Based on the data that has been obtained in the field, it can be seen that most of the lecturers who teach Indonesian courses have realized the importance of using e-learning media for distance learning. However, lecturers still use learning media that are less than optimal and use WhatsApp groups more to provide material, deliver assignments, and accept student assignments. The lecturer did not explore other e-learning media so that students were more interested and challenged in distance learning. This is visible. Namely, 72\% use the WhatsApp group, consisting of all students in 1 class and lecturers who teach courses.

Learning during the COVID-19 pandemic certainly requires media in the learning process. The description of the use of e-learning in Indonesian language learning during the COVID-19 pandemic shows that lecturers understand the importance of choosing and using learning media. However, there are still lecturers whose meetings only provide material via WhatsApp, and no discussion is held. This is done because of the lack of readiness in using various e-learning media in the learning process. Understanding the use of e-learning media needs to pay attention to its benefits as a teacher and student. From the study results, the lecturer also conveyed that there were still many students who were not yet fluent in e-learning. After the eighth meeting, many students who previously did not understand the use of e-learning media Google Classroom, BeL UBT, and Zoom gradually mastered it because they often use and learn with these applications. Several things that need to be considered in choosing and using learning media are 1) effectiveness, 2) relevance, and 3) productive (Musfiqon, 2012). He also added that in choosing learning media, namely 1) adapted to the learning objectives, 2) appropriate, 3) generosity, 4) availability, 5) student circumstances, and 6) teacher skills.

\section{CONCLUSION}

Based on the findings of this study, it can be concluded that E-Learning has proven to be the most effective medium for supporting learning in Indonesian language education courses. In order to anticipate the evolution of the period with the backing of Information Technology, where everything is moving toward the generation of both the mechanism and the content used, an elearning system is required. However, no matter how complex and numerous the e-learning facilities provided by IAIN Manado are, the effectiveness of e-learning is still dependent on the users (teachers and students) of the technology. The unfamiliarity with and lack of preparation of teachers and students in e-learning will result in e-learning not performing at its peak. As a result, teachers and pupils should be able to respond with a positive attitude. Teachers can give students the best possible learning materials by utilizing e-learning. With their preparedness and habit of utilizing e-learning, students can receive the best possible learning resources. To improve the convenience and quality of the teaching and learning process and raise the effectiveness of student learning, e-learning organizers (in this case, IAIN Manado) should continuously create e-learning. The fact that IAIN 
Manado should perform socialization on e-learning to students and a refresher on the usage of elearning to teachers is also crucial.

\section{REFERENCES}

Alexander, S. (2001). E-Learning Developments and Experiences. Education+ Training.

Arsyad, A. (2016). Media Pembelajaran. Jakarta: Raja Grafindo Persada.

Bates, A. T. (2005). Technology, E-Learning and Distance Education. Routledge.

Bozkurt, A., Jung, I., Xiao, J., Vladimirschi, V., Schuwer, R., Egorov, G., ... \& Paskevicius, M. (2020). A global outlook to the interruption of education due to COVID-19 pandemic: Navigating in a time of uncertainty and crisis. Asian Journal of Distance Education, 15(1), 1-126.

Briggs, L. J. (1977). Instructional Design, Principle, and Application. New York: McGraw Hill Book Company.

Budiman, H. (2017). Peran Teknologi Informasi dan Komunikasi dalam Pendidikan. AlTadzkiyyah: Jurnal Pendidikan Islam, 8(1), 31-43.

Cercone, K. (2008). Characteristics of Adult Learners with Implications for Online Learning Design. AACE Journal, 16(2), 137-159.

Clark, R. C., \& Mayer, R. E. (2008). Learning By Viewing Versus Learning by Doing: EvidenceBased Guidelines for Principled Learning Environments. Performance Improvement, 47(9), 5-13.

Clark, R. E. (1994). Media Will Never Influence Learning. Educational Technology Research and Development, 42(2), 21-29.

Darmayanti, T., Setiani, M. Y., \& Oetojo, B. (2007). E-Learning Pada Pendidikan Jarak Jauh: Konsep yang Mengubah Metode Pembelajaran di Perguruan Tinggi di Indonesia. Jurnal Pendidikan Terbuka dan Jarak Jauh, 8(2), 99-113.

El-Hussein, M. O. M., \& Cronje, J. C. (2010). Defining mobile learning in the higher education landscape. Journal of Educational Technology \& Society, 13(3), 12-21.

Elyas, A. H. (2018). Penggunaan Model Pembelajaran E-Learning dalam Meningkatkan Kualitas Pembelajaran. Warta Dharmawangsa, (56).

Falahudin, I. (2014). Pemanfaatan Media dalam Pembelajaran. Jurnal Lingkar Widyaiswara, 1(4), 104-117.

Goyal, S. (2012). E-Learning: Future of Education. Journal of Education and Learning, 6(2), 239242.

Hadisi, L., \& Muna, W. (2015). Pengelolaan Teknologi Informasi dalam Menciptakan Model Inovasi Pembelajaran (E-Learning). Al-TA'DIB: Jurnal Kajian Ilmu Kependidikan, 8(1), 117-140.

Hanum, N. S. (2013). Keefetifan E-Learning Sebagai Media Pembelajaran (Studi Evaluasi Model Pembelajaran E-Learning SMK Telkom Sandhy Putra Purwokerto). Jurnal Pendidikan Vokasi, 3(1).

Iglesias-Pradas, S., Hernández-García, Á., Chaparro-Peláez, J., \& Prieto, J. L. (2021). Emergency Remote Teaching and Students' Academic Performance in Higher Education During The COVID-19 Pandemic: A Case Study. Computers in Human Behavior, 119, 106713.

Jena, P. K. (2020). Impact Of COVID-19 On Higher Education in India. International Journal of Advanced Education and Research (IJAER), 5.

Käpplinger, B., \& Lichte, N. (2020). "The Lockdown of Physical Co-Operation Touches the Heart of Adult Education": A Delphi Study on Immediate and Expected Effects Of COVID-19. International Review of Education, 66(5), 777-795.

Karwati, E. (2014). Pengaruh Pembelajaran Elektronik (E-Learning) Terhadap Mutu Belajar Mahasiswa. Jurnal Penelitian Komunikasi, 17(1), 41-54.

Kerimbayev, N., Kultan, J., Abdykarimova, S., \& Akramova, A. (2017). LMS Moodle: Distance International Education in Cooperation of Higher Education Institutions of Different Countries. Education and Information Technologies, 22(5), 2125-2139.

Kirkwood, A. (2009). E-Learning: You Don't Always Get What You Hope For. Technology, Pedagogy, and Education, 18(2), 107-121.

Liaw, M. L. (2006). E-Learning and The Development of Intercultural Competence. Language Learning \& Technology, 10(3), 49-64. 
Loyens, S. M., Magda, J., \& Rikers, R. M. (2008). Self-Directed Learning in Problem-Based Learning and Its Relationships with Self-Regulated Learning. Educational Psychology Review, 20(4), 411-427.

Mayes, T., \& De Freitas, S. (2007). Learning And E-Learning: The Role of Theory. In Rethinking Pedagogy for A Digital Age (pp. 33-45). Routledge.

Munir, D. (2009). Pembelajaran Jarak Jauh Berbasis Teknologi Informasi dan Komunikasi. Bandung: Alfabeta.

Neuhauser, C. (2002). Learning Style and Effectiveness of Online and Face-To-Face Instruction. The American Journal of Distance Education, 16(2), 99-113.

Osman, M. E. (2020). Global Impact Of COVID-19 On Education Systems: The Emergency Remote Teaching at Sultan Qaboos University. Journal of Education for Teaching, 46(4), 463-471.

Price, L., Richardson, J. T., \& Jelfs, A. (2007). Face-To-Face Versus Online Tutoring Support in Distance Education. Studies in Higher Education, 32(1), 1-20.

Sangster, A., Stoner, G., \& Flood, B. (2020). Insights Into Accounting Education in A COVID-19 World. Accounting Education, 29(5), 431-562.

Seok, S. (2008). Teaching Aspects of E-Learning. International Journal on E-Learning, 7(4), 725741.

Simarmata, J., Abi Hamid, M., Ramadhani, R., Chamidah, D., Simanihuruk, L., Safitri, M., ... \& Salim, N. A. (2020). Pendidikan Di Era Revolusi 4.0: Tuntutan, Kompetensi \& Tantangan. Yayasan Kita Menulis.

Simonson, M., Schlosser, C., \& Orellana, A. (2011). Distance Education Research: A Review of The Literature. Journal of Computing in Higher Education, 23(2), 124-142.

Siritongthaworn, S., Krairit, D., Dimmitt, N. J., \& Paul, H. (2006). The Study Of E-Learning Technology Implementation: A Preliminary Investigation of Universities in Thailand. Education and Information Technologies, 11(2), 137-160.

Sudjana, N. \& Rivai, A. (2011). Media Pengajaran dalam Penggunaan dan Pembuatannya. Bandung: Sinar Baru Algensindo.

Sugiyono, P. (2011). Metodologi Penelitian Kuantitatif Kualitatif dan R\&D. Bandung: Alfabeta.

Suharyanto, S., \& Mailangkay, A. B. (2018). Penerapan E-Learning Sebagai Alat Bantu Mengajar Dalam Dunia Pendidikan. Jurnal Ilmiah Widya, 4(3).

Sumiharsono, R., \& Hasanah, H. (2017). Media Pembelajaran: Buku Bacaan Wajib Dosen, Guru dan Calon Pendidik. Pustaka Abadi.

Tafonao, T. (2018). Peranan Media Pembelajaran dalam Meningkatkan Minat Belajar Mahasiswa. Jurnal Komunikasi Pendidikan, 2(2), 103-114.

Tam, V. C., Chan, J. W., Li, S. C., \& Pow, J. (2018). Developing and Managing School Human Capital for Information and Communication Technology Integration: A Case Study of A School-Based E-Learning Project in Hong Kong. International Journal of Leadership in Education, 21(4), 447-461.

Wahlstedt, A., Pekkola, S., \& Niemelä, M. (2008). From E-Learning Space To E-Learning Place. British Journal of Educational Technology, 39(6), 1020-1030.

Waycott, J., Bennett, S., Kennedy, G., Dalgarno, B., \& Gray, K. (2010). Digital Divides? Student And Staff Perceptions of Information and Communication Technologies. Computers \& Education, 54(4), 1202-1211.

Webb, E., Jones, A., Barker, P., \& Van Schaik, P. (2004). Using E-Learning Dialogues in Higher Education. Innovations in Education and Teaching International, 41(1), 93-103.

Wu, J. H., Tennyson, R. D., \& Hsia, T. L. (2010). A Study of Student Satisfaction In A Blended ELearning System Environment. Computers \& Education, 55(1), 155-164. 